\title{
Marine benthic faunal successional stages and related sedimentary activity*
}

\author{
RUTGER ROSENBERG \\ Department of Marine Ecology, Göteborg University, Kristineberg Marine Research Station, \\ 45034 Fiskebäckskil, Sweden.
}

\begin{abstract}
SUMMARY: This paper is a brief review of successional stages and activity of benthic soft-bottom communities. Benthic communities was first described by Petersen in the 1910s and further developed by Molander, Thorson and Margalef. Successional stages of benthic communities chance in a predictable way in relation to environmental disturbance and food availability. Food supply to the bottom can occur as a vertical flux, but transport through lateral advection is more important in some areas. While at the bottom, the infauna processes the food in many different ways, and the feeding modes can be categorised into more than 20 functional groups, but fewer are present in brackish water. This categorisation is based on animal mobility and where and how they ingest the food. Animal activity in the sediment, bioturbation, has a significant effect on redox conditions and diagenetic processes. Structures in the sediment due to infaunal presence and activity can be observed in situ by sediment profile imaging, and the biogenic structures and redox conditions can be parameterised and have been shown to correlate to benthic community successional stages. The largest threat to benthic faunal biodiversity is the spread of near-bottom oxygen deficiency in many enclosed are stratified coastal areas.
\end{abstract}

Key words: benthos, bioturbation, functional group, benthic-pelagic coupling, deposit feeder, hypoxia.

\section{INTRODUCTION}

Pioneer in marine benthic ecology was the Danish scientist C.G.J. Petersen, who in the 1910s in several papers described benthic communities in Scandinavian waters, (e.g. Petersen, 1913). The different communities were named after dominant or conspicuous species, e.g. the bivalve Macoma, the brittle star Amphiura and the polychaete Melinna, according to when different species showed dominance. Petersen's work was later followed up by other Scandinavians, notably Molander (1928) and Thorson (1957). Molander described 9 different community types and 12 sub-communities

\footnotetext{
*Received May 15, 2001. Accepted June 12, 2001.
}

("facies") in the Swedish Gullmarsfjord. Thorson stated that benthic communities were true ecological units and partly separated from each other. He developed Petersen's ideas further and opened the global ecological perspective by showing that benthic communities in Scandinavian waters had ecological parallels in the world oceans. This is here illustrated by an example from benthic communities in Arctic, Boreal, and Northeast Pacific waters showing parallelism between Macoma communities (Fig. 1).

Beginning in the 1950s, the Spanish scientist Ramón Margalef developed his ideas about marine ecosystems into a new paradigm. In his view, ecosystems develop over evolutionary times to work unified and in a cybernetic way with feed back loops that synchronize the ecosystem function. In the book 


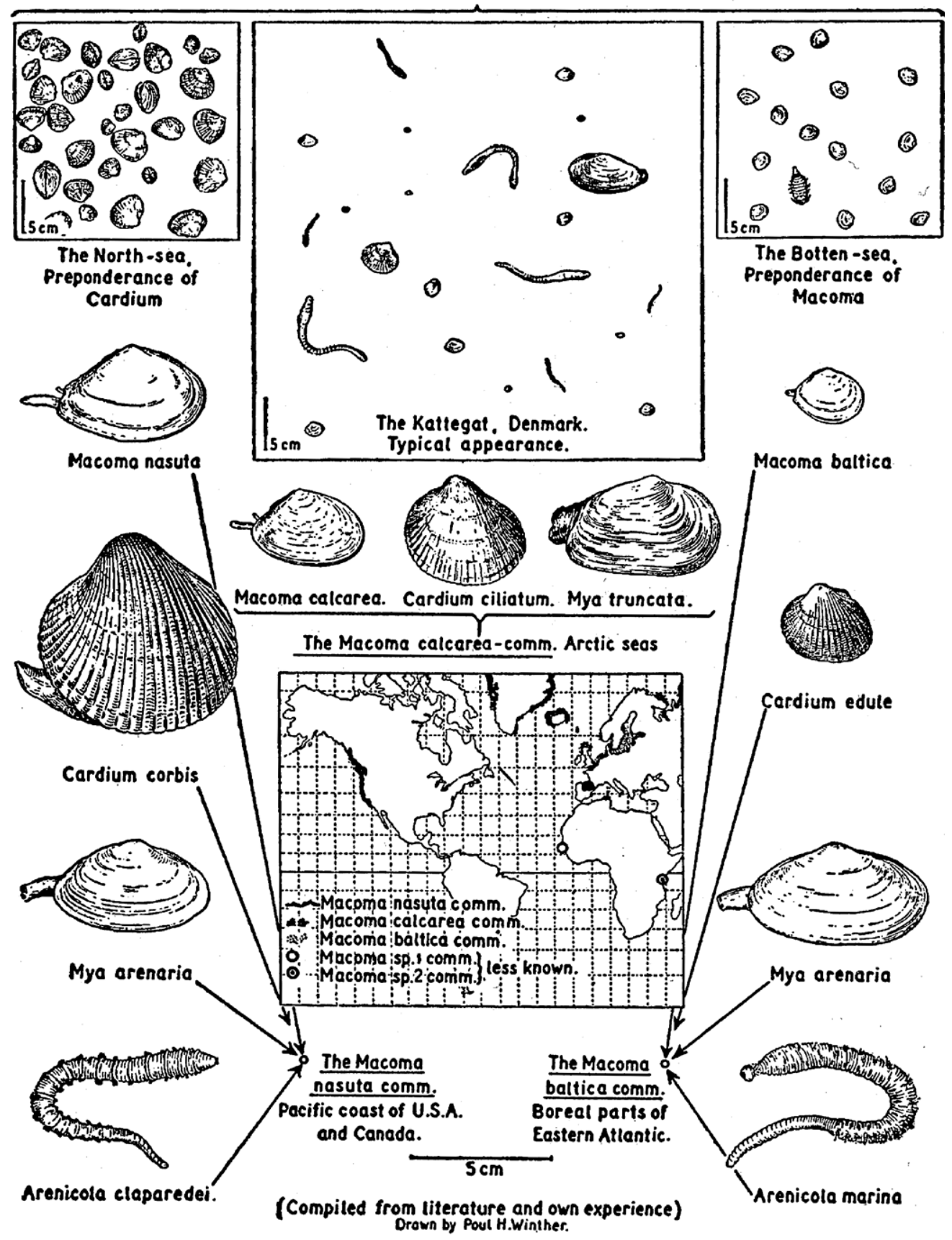

FIG. 1. - Illustration of benthic parallel communities with examples from the eastern Atlantic and the Pacific coast of the USA exemplified with the distribution of some bivalve and polychaete genera in both regions (from Thorson 1957).

"Perspectives in Ecological Theory", Margalef (1968) described succession as "the occupation of an area by organisms involved in an incessant process of action and reaction which in time results in changes in both the environment and the community, both undergoing continuous reciprocal influence and adjustment". Margalef further stated that the process of succession is equivalent to a process of accumulating information, and that the final stages of succession should preferably be called "mature ecosystems" and not labelled "climax" as in earlier ecological literature.

Marine benthic communities are frequently characterised by their number of species, abundance and biomass (SAB). Pearson and Rosenberg (1978) showed that these parameters change in a predictable way along a gradient of disturbance, both in time and space (Fig. 2). In a later paper, Pearson and Rosenberg (1987) further developed the concept that food availability is a major structuring factor for 
benthic communities, i.e. under low food conditions $\mathrm{SAB}$ is also low and when food is abundant the values of SAB are significantly higher. Food for the benthos is generally higher in shallow and coastal areas than in offshore and deeper areas. Over the last decades, the increased input of nutrients has lead to increased primary production and consequently more organic material has accumulated on the bottoms. In enclosed and stratified sea areas, the oxygen consumption can be higher than the supply, leading to oxygen deficiency and reduction of benthic communities.

This review focuses on benthic macrofaunal structural changes in relation to various degrees of disturbance and on the impact of the infaunal activity for biogeochemical processes in the sediment. It is restricted to coastal seas and soft sediments. The first part deals with food supply to the benthos and functional feeding groups, and bioturbation. The role of biogenic structures for redox conditions and chemical processes in the sediment are further discussed. Finally, succession of benthic communities is illustrated with a few examples, particularly in relation to increased oxygen deficiency followed by re-oxygenation. Arntz et al. (1999) have recently, in a partly provocative paper, reviewed several aspects related to benthic fauna: interaction, diversity, larval settlement and recolonisation. These aspects are therefore not treated in the present paper.

\section{BENTHIC-PELAGIC COUPLING}

In the beginning of the 1980s, scientists from Kiel delivered significant contributions to the understanding of the role of phytodetritus as food for the benthic system (Graf et al., 1982; Smetacek, 1984). They showed that in the shallow waters off Kiel, the benthic response to a settling phytoplankton bloom occurred within less than one week. The immediate

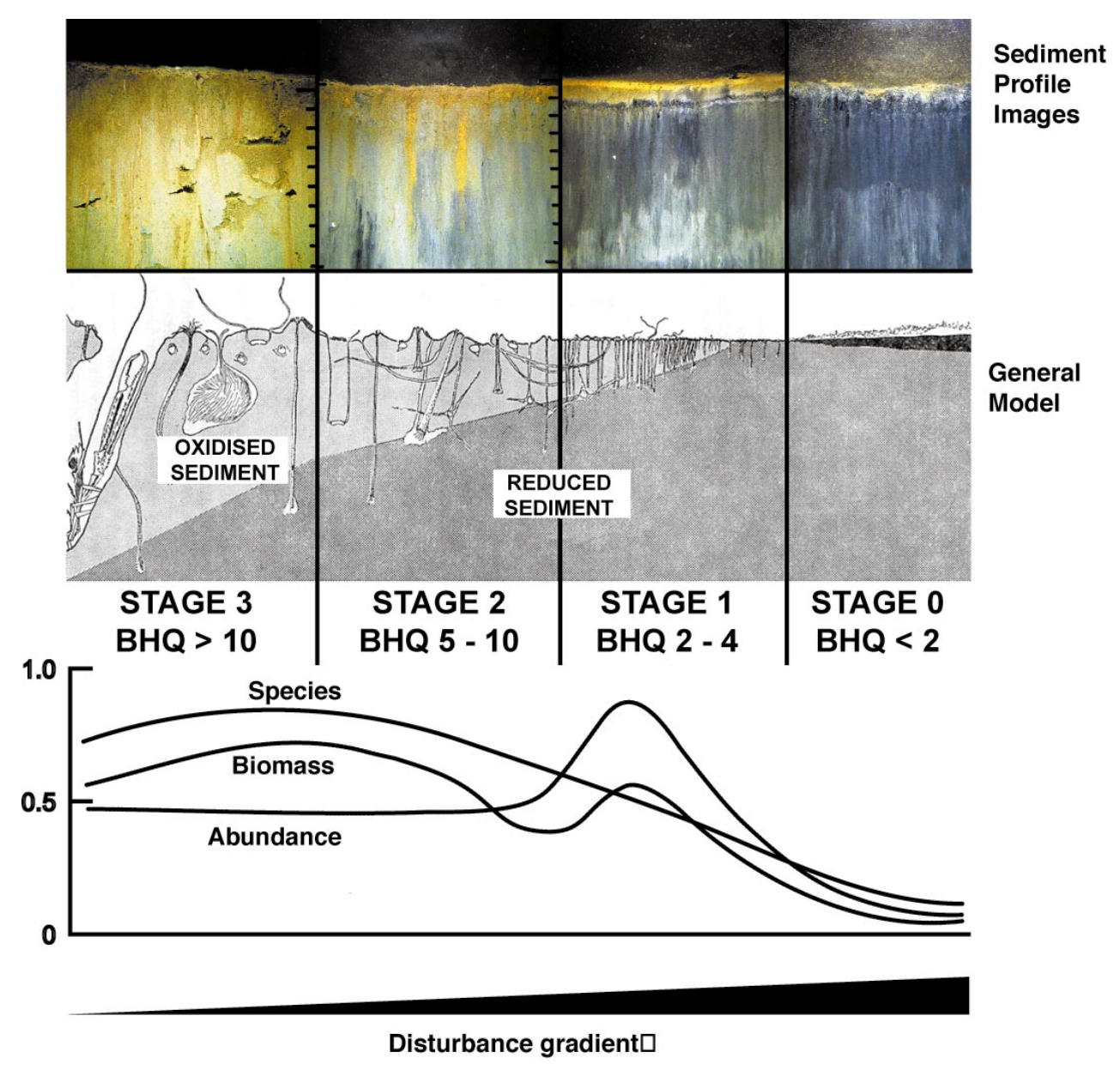

FIG. 2. - General model of distribution of benthic infaunal successional stages along a gradient of increased environmental disturbance from left to right (after Pearson and Rosenberg 1978) and the associated Benthic Habitat Quality (BHQ) index (Nilsson and Rosenberg 1997). Sediment profile images assigned to a successional stage are mounted above the general model (colours are digitally enhanced), where oxidised sediment is rust-brown and reduced sediment is grey or black. In the bottom of the figure the generalised species (S), abundance (A), biomass (B) diagram are illustrated (after Nilsson and Rosenberg 2000). 
response of primarily bacteria and meiofauna was demonstrated by increased heat production and oxygen consumption. Graf suggested that most macrofaunal species were too slow to obtain the freshly deposited phytoplankton, but could probably later consume some of the smaller organisms. It has later been shown that maldanid polychaetes can readily react to newly deposited phytodetritus by subducting food, without immediate ingestion, from the sediment surface down to depths of $10 \mathrm{~cm}$ or more (Levin et al., 1997). In a summary about benthic-pelagic coupling, Graf (1992) emphasised the importance of quality of the settling material for the magnitude of the response of the benthic system. The organic part of freshly deposited phytoplankton was more or less completely mineralised in a few days.

Settling phytodetritus after a bloom may have $\mathrm{C} / \mathrm{N}$ weight ratios of about 7 , close to the value of plankton algae of between 5 and 6 , but the ratio may be $>10$ later in the season. Gray (1992) reviewed the usefulness of $\mathrm{C} / \mathrm{N}$ ratios for assessing the nutritious quality of settling material. He found that $\mathrm{C} / \mathrm{N}$ ratios generally are low in coastal surface waters, and that they are higher in the open ocean, around 14. In comparison, the $\mathrm{C} / \mathrm{N}$ ratios in vascular plants may go up to 100 , showing that they are particularly refractory. The rates of organic matter decomposition and microbial growth have been found to be inversely correlated with age and $\mathrm{C} / \mathrm{N}$ ratios of the substrate (Kristensen and Blackburn, 1987). Smetacek (1984) and Graf (1992) showed that in boreal systems, the main food supply to the benthos is pulsed and enhanced twice a year; after the spring and autumn blooms. Wassmann (1990) studied the relation between primary production and "export production", i.e. he estimated the amount of carbon that is transported downwards from the photic zone. He found a linear correlation during moderate primary productions, but during enhanced nutrient conditions and primary production, but the export production increased in an exponential way. Export production is, however, dependent on phytoplankton species composition and grazing intensity and is suggested to vary in relation to this and hydrographical features.

General models describing the coupling between the pelagic and the benthic systems have been presented by Ott (1992). These models were developed for the Adriatic Sea in the Mediterranean, but some are applicable also for other marine systems (Fig. 3). In oligotrophic, deep waters most of the organic
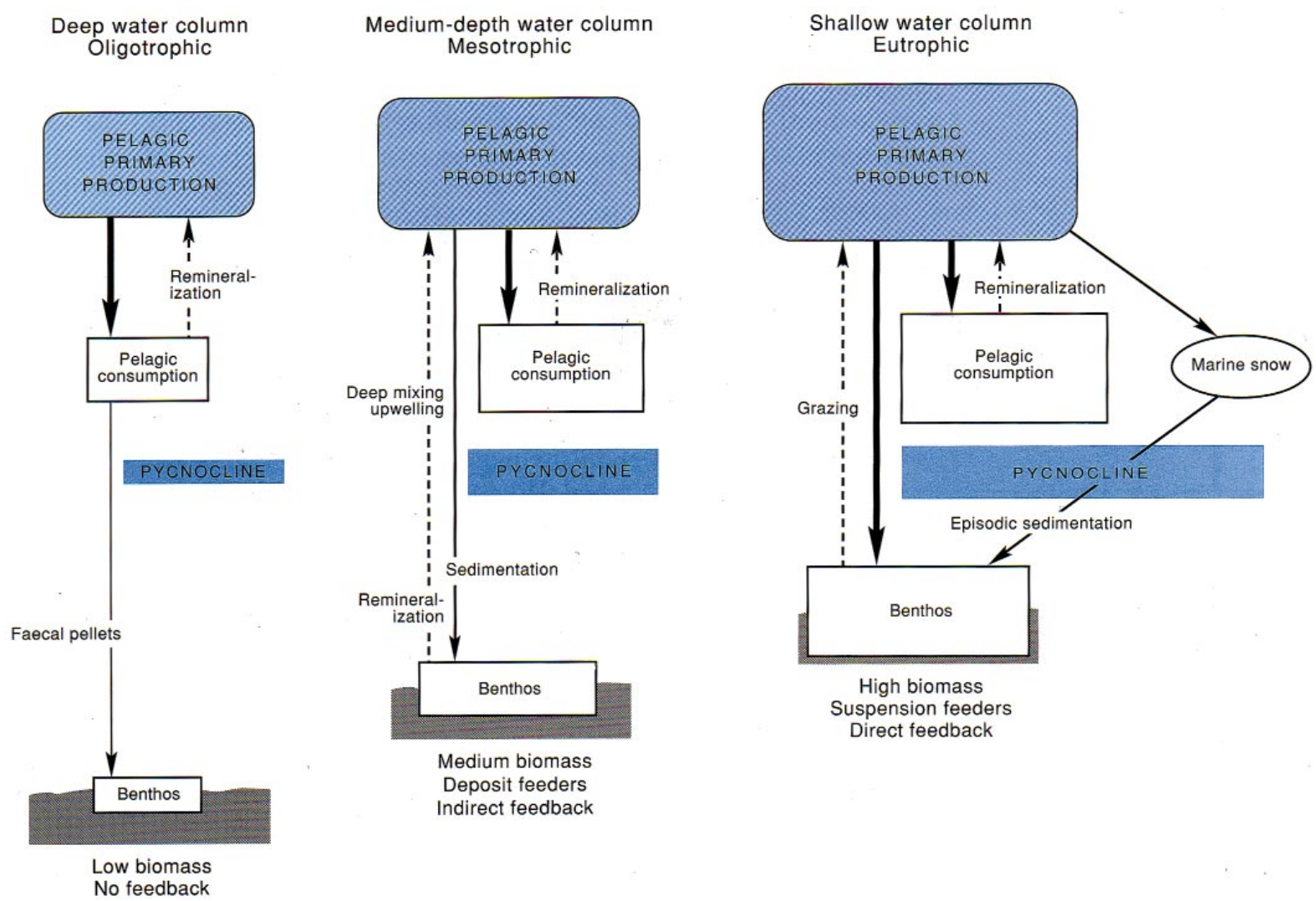

FIG. 3. - General model of benthic-pelagic coupling from the Adriatic Sea in the Mediterranean Sea showing the sedimentation of organic matter under different trophic conditions and the importance of a pycnocline (from Ott 1992). 


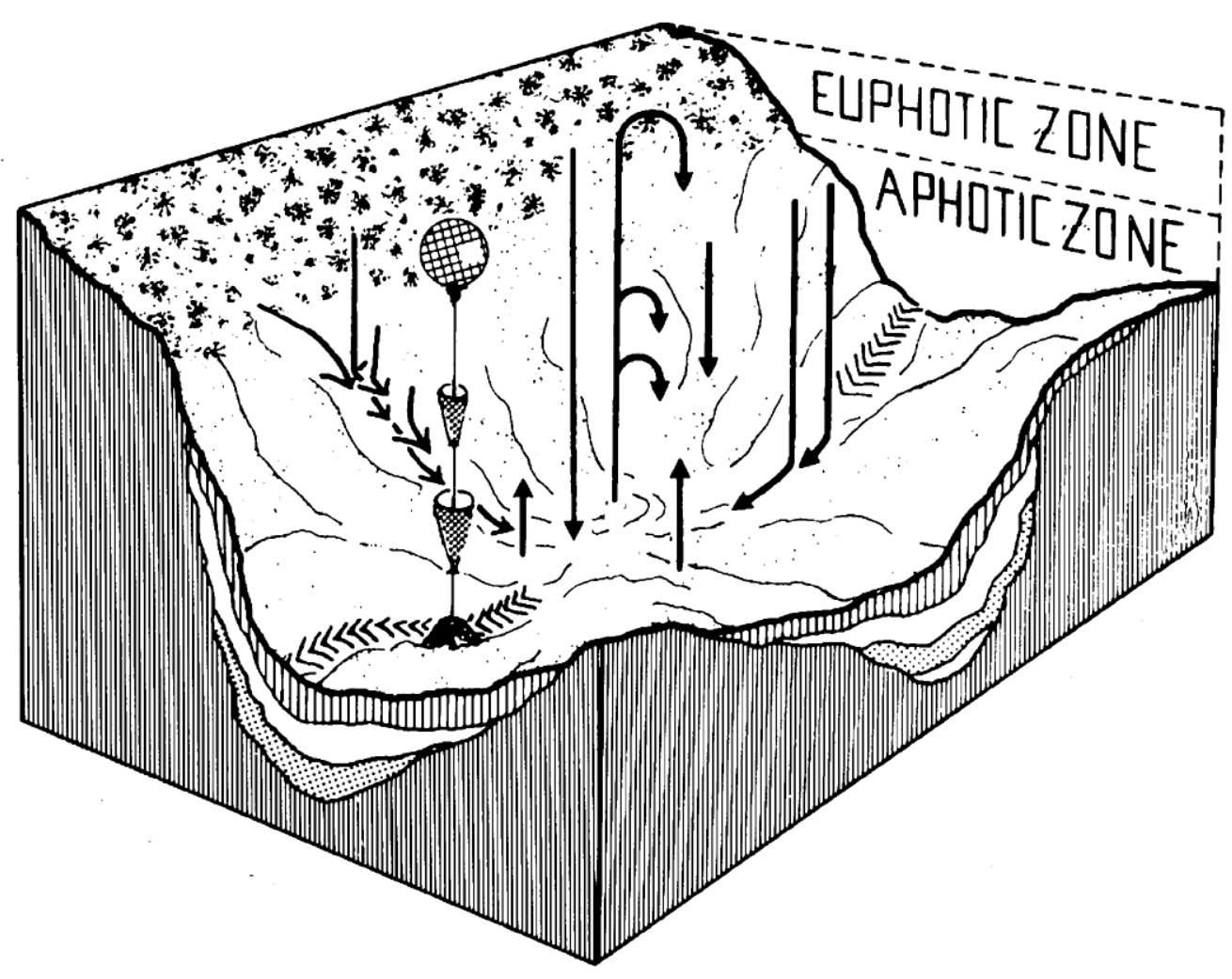

FIG. 4. - Dynamic model of benthic-pelagic coupling showing the particle input to the bottom through vertical sedimentation, lateral advection or resuspension, and possible fluxes out from the sediment to the water column (from Graf 1992).

material will be mineralised in the water column, and the fraction that reaches the bottom will be largely refractory. In mesotrophic waters and medium depths (shelf to $<500 \mathrm{~m}$ ), the primary production is higher, and the food supply to the pelagic and benthic compartments is higher than in the oligothrophic example. In more eutrophic, shallow waters, primary production is even higher, a large proportion is mineralised in the pelagos above the pycnocline, and the largest settlement of organic carbon on the bottom occurs seasonally, mainly after bloom periods. When the pycnocline is strong, this barrier may act as a secondary bottom. Thus, some material will be trapped here and partly mineralised, but may eventually form aggregates and later settle on the sediment. Thus, material that settles on deeper bottoms and below pycnoclines is likely to be of poor nutrient value during most periods of the year.

In most models, food supply to the benthos is depicted as a vertical flux (see Fig. 3). However, transport of organic matter through lateral advection may be 2 to 8 times greater as lateral velocities are higher than vertical transport rates (Graf, 1992; Fig. 4). Suspension feeders, which can be both epifauna and infauna, benefit from seston being advected ver- tically above the bottom. It has been shown in shallow areas, such as the San Francisco Bay (Cloern, 1982), SE Kattegat (Loo and Rosenberg, 1989) and in a Danish estuary (Petersen and Riisgård, 1992), that benthic suspension feeders can have a significant impact on the phytoplankton biomass in the water column. The capacity of the filter feeders in these examples was so great that theoretically the whole water mass could be cleared from phytoplankton within a few days. Measurements of secondary production of shallow water suspension feeding bivalves have demonstrated that the annual production can be significantly greater than the primary production per unit area (Möller and Rosenberg, 1983). Thomsen et al. (1995) studied the importance of vertical transport for the food supply to the benthos along a continental slope in the Barents Sea. They also found that lateral flux was much more important for particle transport than vertical flux. Thus, lateral advection and turbulent processes are, in addition to vertical transport processes, important for the benthic-pelagic coupling.

Many inorganic and organic particles that have settled on the sediment surface will be resuspended and transported by currents. Physically induced 
resupsension of particles are particularly important on exposed shallow bottoms, on slopes and on bottoms where the currents are strong. Accumulation of particles occurs at greater depths and where bottom currents are low (Eisma and Kalf, 1987). Activity of benthic fauna, e.g. bioturbation, biodeposition and bioresuspension, has also an important role in resuspension (Davis, 1993; Graf and Rosenberg, 1997). The latter authors emphasise that although it is obvious how important biologically mediated resuspension can bee, very few investigations exist, which quantify the flux across the sediment-water interface. Boudreau (1997a) modelled the effect of bioresuspension and found that in some circumstances the bioresuspension may enhance particle exchange by 10 times between the sediment and the water column. This clearly shows the potential effect benthic animals might have on particle transport above the bottom. Further investigations are needed to assess the ecological impact of bioresuspension.

A tight coupling between dynamic processes close to the bottom and the infauna has also been demonstrated from other offshore areas. In the North Sea, at a tidal front area off the Dutch coast, a dramatic decline in current speed over a short distance has proven to have a great impact on food supply to the bottoms. This in turn affected the distribution of the benthic communities, which changed over short distances (Creutzberg et al., 1984). The brittle star Amphiura filiformis was one abundant species that was favoured by these changing conditions in food supply. In another study in the North Sea, Dauwe et al. (1998) similarly found that the distribution of benthic communities was related to bottom dynamic factors and food supply. The highest diversity of trophic groups, largest individual sizes and the deepest distribution were found in sediment with organic matter of intermediate quality and quantity. Rosenberg (1995) studied the benthic faunal composition off the Swedish west coast in an area with extremely high resuspension and sedimentation rates. The slope with a very high food supply harboured an extremely rich fauna. Dominant in abundance and biomass was Amphiura filiformis. This species is commonly found on muddy bottoms all over the North Sea and adjacent areas, but not in such great quantities as found here, $\approx 3000$ ind. $\mathrm{m}^{-2}$. A high and probably nutritious food supply was suggested to be the key to these extremes. Moreover, A. filiformis can feed both as a passive suspension feeder and as a deposit feeder, which would be an advantage during variable current speeds and supplies of food.
High quantities of benthic fauna on the Swedish west coast were correlated with rich food supply, which made Rosenberg (1995) suggest that the benthic fauna generally is food limited. The quality of the food would normally be higher in suspended particulate matter than in deposited. In an experiment, Taghon and Greene (1992) studied the growth rates in two polychaetes, which could switch from deposit feeding to passive suspension feeding. One species, Boccardia pugettensis, grew better while suspension feeding, whereas the other, Pseudopolydora kempi japonica, grew better while deposit feeding.

A large proportion of the sediment surface is probably searched for food more or less continuously. In an experiment with natural infauna and sediment from $70 \mathrm{~m}$ depth in a Swedish fjord, Duchêne and Rosenberg (2001) recorded the activity on the sediment surface by video numeric tracking. They recorded that about one-fourth of the area had infaunal activity over a $4 \mathrm{~h}$ period. When phytodetritus was added to the same surface area, the areas searched by the fauna almost doubled over he next 4 h. The most active species was Amphiura filiformis, which showed an immediate response to the food supply. This species is able to rapidly collect food supplied on the sediment and to ingest and store the food within the sediment at a depth of a few centimetres (Rosenberg et al., 1997). Similarly, Levin et al. (1997) have shown from in situ observations that tube-building polychaetes, maldanids, rapidly can subduct freshly deposited phytodetritus to depths of $10 \mathrm{~cm}$ or more into the sediment. This material will be available to microbes and infauna at these depths in the sediment.

\section{FUNCTIONAL GROUPS}

Benthic fauna is generally divided into five feeding categories: suspension feeders, surface deposit feeders, sub-surface deposit feeders, herbivores and carnivores. This is for some species a simplified classification and overlap occurs, e.g. some species can successfully switch between surface deposit feeding and suspension feeding, e.g. the brittle star Amphiura filiformis. In the classical paper by Fauchald and Jumars (1979): "The diet of Worms" the basic classification of feeding modes was divided further and 22 different guilds were defined for polychaetes. These were based on feeding habits, type of food and motility. Lee and Swartz (1980) 


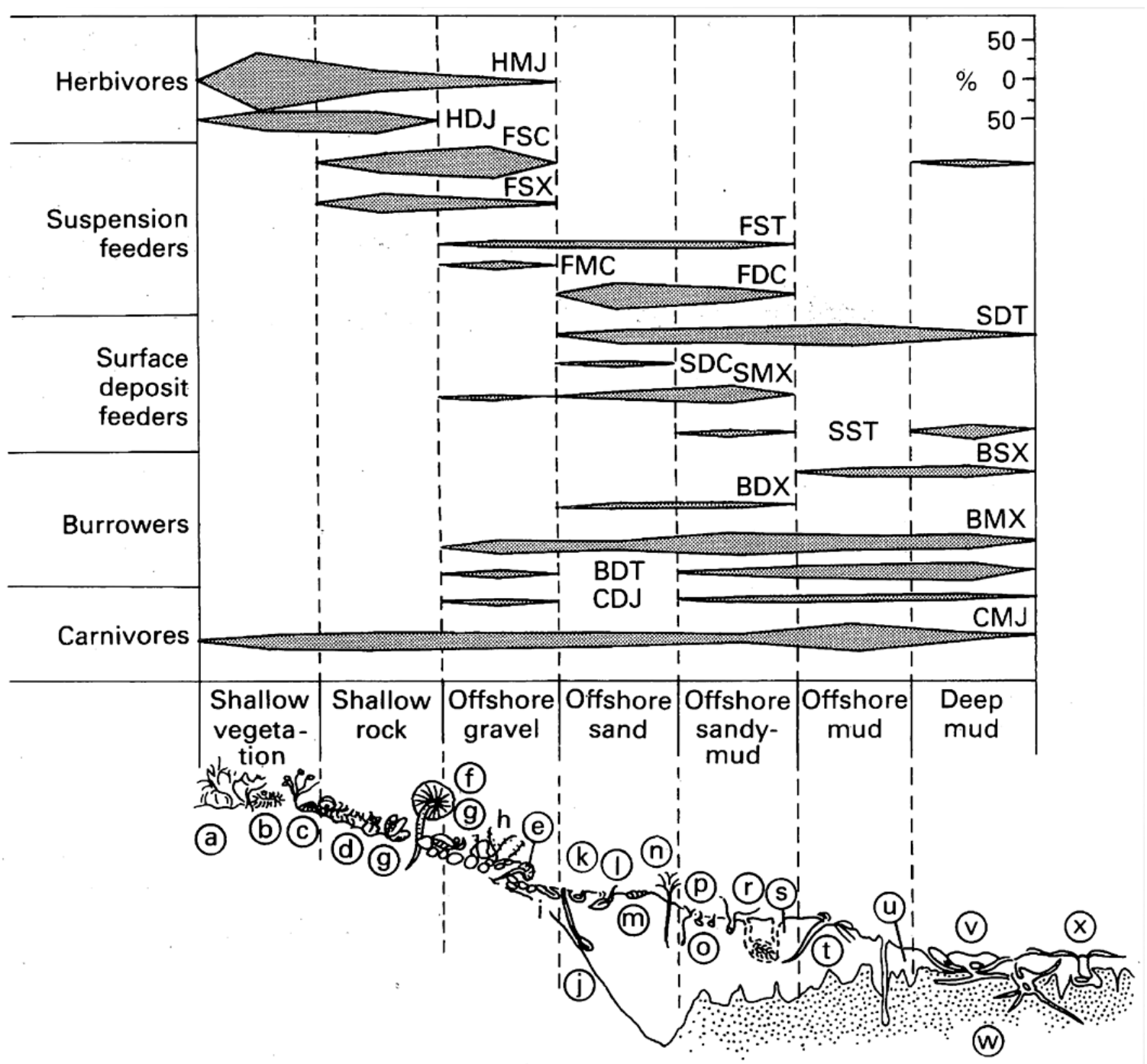

FIG. 5. - Distribution of benthic faunal groups in boreal communities along a gradient of decreasing food availability and water movement with increasing depth. Key to functional groups: Feeding type: H, herbivore; F, suspension feeder; S, surface deposit feeder; B, burrowing deposit feeder; C carnivore. Degree of mobility: M, mobile; D, semi-mobile; S, sessile. Feeding habit: J, jawed; C, ciliary mechanism; T, tentaculate; X, other types. Key to taxa illustrated at bottom is in the original reference (from Pearson and Rosenberg 1987).

classified benthic invertebrates into 12 guilds in relation to bioturbation processes: epifauna or infauna, mobile or stationary, and deposit or suspension feeder. These papers inspired Pearson and Rosenberg (1987) to their paper "Feast and Famine", where they expanded the previous classification in categorising benthic boreal communities. In addition to the feeding and mobility modes described above, they used 3 degrees of mobility (mobile, semi-mobile and sessile) and 4 modes of feeding habit (jawed, ciliary mechanisms, tentaculate, and other). They graphically showed (Fig. 5) the habitat related depth distribution of these functional groups, where herbivores and suspension feeders had their main distribution in shallow waters, deposit feeders were to be more abundant on accumulation bottoms and carnivores were found in all habitats. This gen- eralized model suggested that the highest diversity of functional groups could be found in offshore sandy mud. The use of the term functional groups is a wider concept compared to a guild. Animals in the same feeding guild commonly compete for the same food resource, whereas such interaction does not necessarily occur within a functional group.

Diaz and Schaffner (1990) made similar classifications of the benthic communities in Cheaspeake Bay, USA. They stated that feeding methods and rates of the benthic fauna were among the most important variables influencing sediment modification. They suggested that, in addition to feeding type and mobility mode, also defecation mode should be included for the classification into functional groups. Bonsdorff and Pearson (1999) expanded the functional group classification used by Pearson and 
Rosenberg (1987) to include 25 units. They applied that scheme to benthic communities from the northern part of the Gulf of Bothnia, with a salinity of only 1 psu, along a gradient of increasing salinities in the Baltic, Kattegat, Skagerrak and to a Scottish sea loch (34 psu). The number of functional groups on depths $>50 \mathrm{~m}$ increased with increasing salinity from 3 in the Gulf of Bothnia to about 20 in the Kattegat/Skagerrak. In the Baltic, only one group of (mobile) sub-surface deposit feeders was found, but 5 groups occurred in the Kattegat/Skagerrak. Thus, the functional biodiversity, reflected in different feeding modes and mobility, correlated with increased salinity. On 4 stations in the North Sea, with similar salinities, Dauwe et al. (1998) found instead that the different composition of trophic groups of the benthic fauna was related to food availability, which also was suggested by Pearson and Rosenberg (1987).

\section{BIOTURBATION}

Bioturbation is related to several different activities of benthic infauna: deposit feeding, reworking, construction of burrows and tubes, and irrigation. All have significant effects on biogeochemical processes in the sediment and at the sedimentwater interface, and on redox conditions in the sediment. Rhoads (1974) was one of the pioneers in this field of research, and in the review of organism-sediment relations he also emphasised the ecological role of biodeposition by benthic animals. Rhoads was the first scientist to show in situ sediment profile images to illustrate biogenic structures in the sediment (see Fig. 2).

Several other American scientists have made significant contributions to the biology of deposit feeders. Lopez and Levington (1987) and Jumars and Wheatcroft (1989) elegantly described the life of deposit feeders: they account for the largest bioturbation of particles, they feed on a remarkably poor food source, most species are selective feeders, and they separate sites of ingestion and egestion. Many deposit feeders seem to mainly ingest microbes associated with particles (microbial stripping), as they do not have the digestive capability of fresh phytodetritus. Lopez and Levinton (1987) summarised feeding rates for 20 deposit feeding invertebrates and found that they daily processed at least the same amount of sediment as their own body weight, often much more.
To estimate the amount that sediment deposit feeders may bioturbate, I have made the following simplifications. Assume that the biomass of deposit feeders is $120 \mathrm{~g} \mathrm{~m}^{-2}$, and that they may be able to rework at least the same amount of sediment daily. If we also assume that the deposit feeders are evenly distributed down to $10 \mathrm{~cm}$ depth in the sediment and bioturbate that part of the sediment (Boudreau, 1997b) (sediment volume is then $100 \mathrm{dm}^{3}$ equivalent to $\approx 120 \mathrm{~kg}$ ), they may process about one-third of this superficial sediment per year. However, more recently Sandnes et al. (2000) documented that large animals, e.g. heart urchins such as Ecinocardium cordatum, may dominate the reworking process in some areas, and when they are present larger volumes than those exemplified here might be bioturbated annually.

Animal tubes have a fixed structure in the sediment, whereas burrows have a considerable variation and the volume not utilized permanently by the occupant is generally much larger in burrows than in tubes (Lee and Swartz, 1980). Burrows and tubes are micro-environments of chemical significance to sediment-water exchange processes, but measurements of tubes and burrows and their extension in the field is limited to a few examples in the literature. Hylleberg and Henriksen (1980) and Fenchel (1996) have shown that populations of the polychaetes Nereis virens and $N$. diversicolor, and the amphipod Corophium volutator through their burrowing activity significantly increase the oxic conditions within the sediment. Similarly, Davey (1994) found the increase of surface area due to a natural population of Nereis diversicolor to be about $300 \%$. Mainly burrows of large thallassinidean crustaceans have been investigated by the resin cast technique, (e.g., Astall et al., 1997). Architecture of burrow systems has also been studied by X-radiography (e.g. Schaffner, 1990).

Several experimental studies have shown the ecological importance of infaunal bioturbation, irrigation, burrow and tube structures for biogeochemical processes. For example, Forster and Graf (1992) calculated for Callianassa subterranea a $0.7 \mathrm{~m}^{2}$ burrow surface area subjected to oxygenation below every $\mathrm{m}^{2}$ of sediment surface. In situ sediment profile images from the Kattegat clearly demonstrated the great effect of large crustacean burrows on redox conditions in the sediment (Fig. 6). Hylleberg and Henriksen (1980) estimated that the increase in oxic sediment volume due to bioturbation would be 30 to $50 \%$ for 2000 ind. $\mathrm{m}^{-2}$ of the polychaete Nereis virens and 100 to $150 \%$ for 6000 ind. $\mathrm{m}^{-2}$ of the 


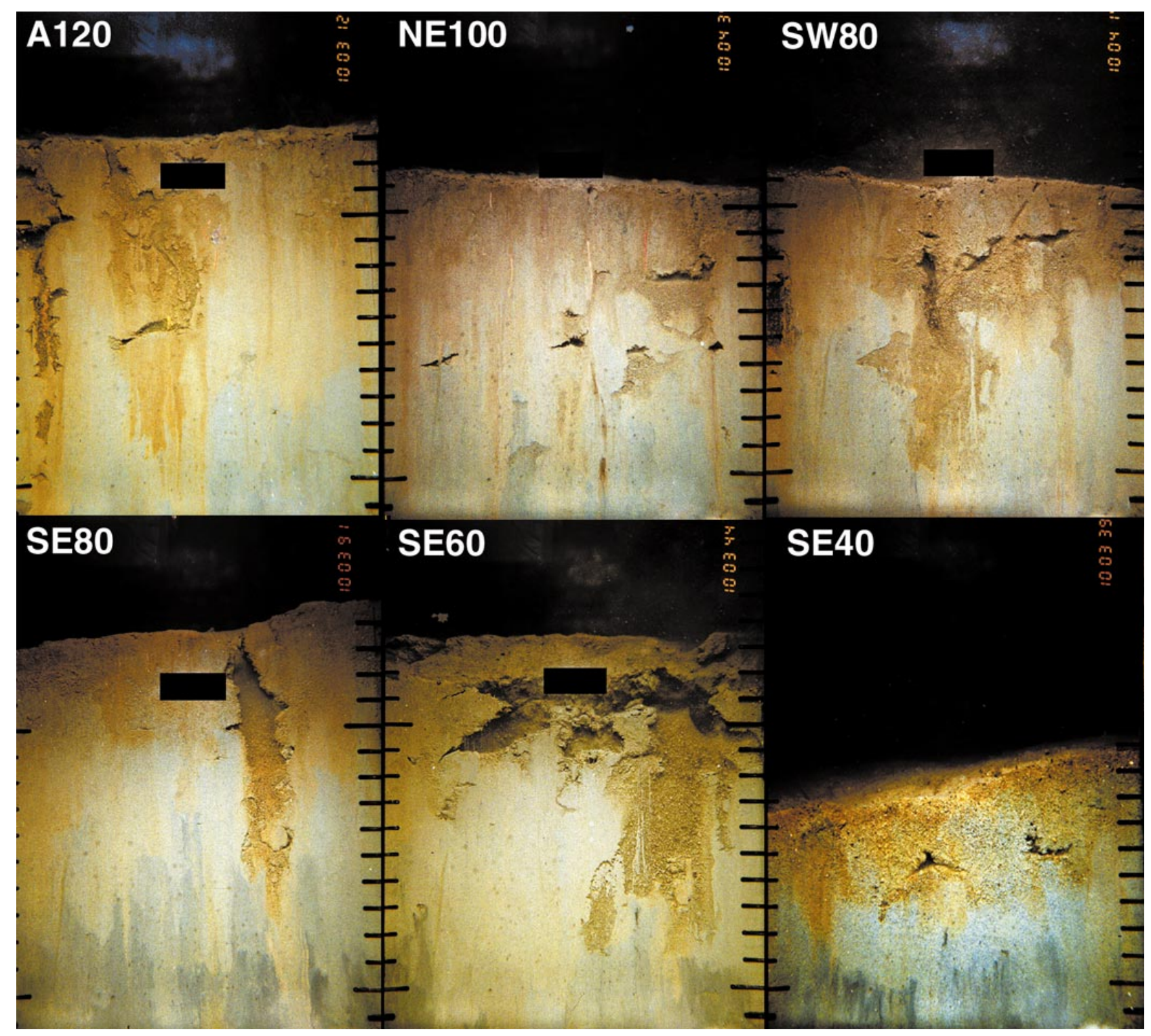

FIG. 6. - Sediment profile images from depths between 40 and $120 \mathrm{~m}$ in the Kattegat (West Sweden). The yellow colour indicates the oxidised sub-oxic zone and the darker zone is reduced sediment (colours are digitally enhanced). The large burrows at 60 to $120 \mathrm{~m}$ depth are probably made by the crustaceans Calocaris macandreae and Maera loveni. Several polychaetes are seen in the image from $100 \mathrm{~m}$ and appear to be Heteromastus filiformis. The vertical scale is centimetres, and the black rectangle masks reflections of the flash (from Rosenberg et al., 2000).

amphipod Corophium volutator. The authors concluded that bioturbation increases the rates of both nitrification and denitrification. Similarly, Mayer et al. (1995) found that macrofaunal burrows and tubes greatly enhanced the nitrification potential compared to that of oxidised surface sediments. Experiments conducted in situ in the Mediterranean demonstrated a 160 to $280 \%$ greater denitrification potential with infauna compared to in defaunated sediments (Gilbert et al., 1998). The burrow walls are important sites for nitrification-denitrification processes in the sediment, since these require a juxtaposition of oxic and anoxic micro-habitats (Jenk- ins and Kemp, 1984). Reworking of surface sediment by the sea urchin Brissopsis lyrifera was shown to increase oxygenation and precipitation of phosphate, and to decrease the denitrification rate (Widdicombe and Austen, 1998). Ockelmann and Muus (1978) estimated that a single Amphiura filiformis can oxidise an area of $35 \mathrm{~cm}^{2}$ in the sediment, mainly around the disc. Based on that figure, Rosenberg (1995) estimated that high densities (3000 ind. $\mathrm{m}^{-2}$ ) of A. filiformis, as found in the northern Kattegat, might oxidise an area in the sediment of about $10 \mathrm{~m}^{2}$ per $\mathrm{m}^{2}$ surface area. Aller and Aller (1998) used sediment plugs to simulate spacing of individ- 
ual burrow structures in the sediment. They found that the specific geometry of burrow sections was likely to have significant localized effects on chemical fluxes and microbial activity. Further, macrofauna enhanced solute transport 2 to 10 times more than meiofauna (Aller and Aller, 1992). Thus, we have evidence that macrofaunal bioturbation are important for sediment geochemistry and that the infaunal species are important ecological engineers. The challenge for future research is to improve the quantification of these processes and assess their role in the marine ecosystem.

\section{FAUNAL SUCCESSION AND ASSOCIATED SEDIMENT CHANGES}

Structural changes in marine benthic communities caused by different disturbances such as organic enrichment and physical forces seem to be rather predictable and follow models presented by Pearson and Rosenberg (1978) and Rhoads and Germano (1986). Since their appearance, the models have been tested repeatedly and seem to be generally applicable to various types of changes in many habitats (Heip, 1995). Timing of a disturbance may have a significant effect on succession, particularly in shallow coastal waters as was shown in a study in Connecticut, USA. Zajac and Whitlatch (1982) found that benthic community succession after a disturbance in spring was followed by high species numbers and densities, whereas a disturbance in the autumn was followed by few species in low numbers. In the original models, the importance of biogenic structures for the sedimentary redox conditions was indicated in a schematic way. Recently that part of sedimentary information in the model was supplemented by sediment profile images (SPIs) taken in situ during temporal decline in oxygen concentrations in the Gullmarsfjord in the Skagerrak (Nilsson and Rosenberg, 2000; Fig. 2).

The SPI technique was developed by Rhoads and co-workers (Rhoads and Cande, 1971; Rhoads and Germano, 1982, 1986) and it is a cost-effective method to obtain rapid information about the relations between faunal activity, biogenic structures and redox conditions in the sediment. In contrast to grab samples for information about composition and quantitative assessment of the macrofauna, SPI is a non-destructive method that gives information of faunal structures, infaunal activity and chemical properties of the sediment. In the study cited above from the Gullmarsfjord, it was shown that the sedimentary habitat changed gradually with declining oxygen concentrations in the water above the bottom, and this was correlated with decline in the SAB variables (Nilsson and Rosenberg, 2000). By digitally analysing the SPIs, contrasts between colours of the sediment can be enhanced. Thus, the redox potential discontinuity (RPD), i.e. the zone between oxidised (rust-brown) and reduced (black) sediment, can be determined and the oxidised areas quantified. Following dissolved oxygen, which only penetrates a few millimetres into the mud (Revsbech et al., 1980), the oxidising agents in the oxidised (sub-oxic) zone are in sequence: $\mathrm{NO}^{-\mathrm{III}}, \mathrm{Mn}^{+\mathrm{IV}}$ and $\mathrm{Fe}^{+\mathrm{III}}$ (Aller, 1988). A significant correlation between measurements of the RPD in the sediment has been obtained between measurements with electrodes and with digital analysis of SPIs (Rosenberg et al., 2001).

Nilsson and Rosenberg (2000) showed that the four successional stages of the benthic communities in the Pearson-Rosenberg model determined from SAB-curves were significantly correlated with a benthic habitat quality (BHQ) index determined from SPIs. The BHQ index is based on parameterisation of (1) sediment surface structures, (2) subsurface structures, and (3) mean depth of apparent RPD (Nilsson and Rosenberg, 1997). The BHQ index summarises a maximum of 5 scores from each of these three estimates and varies between 0 and 15 (see Fig. 2 for assignment of BHQ to benthic faunal successional stages).

In recent studies by Nilsson and Rosenberg (2000) and Rosenberg et al. (manuscript), the successional changes of $\mathrm{SAB}$ of the benthic fauna from grab samples and from SPIs were followed during a two-year recovery period subsequent to re-oxygenation of the Gullmarsfjord initiated in April 1998. We can show, for the first time, how benthic communities during decreased and long-term (months) oxygen deficiency deteriorated to poor maturity successional states, and how they successively recovered during re-oxygenation towards mature community states of a similar structure as before the disturbance by hypoxia. The recovery at four stations during 2 years was an almost successive increase for number of species, abundance and biomass. The benthic communities returned to an almost identical faunal structure with the same dominants. Similarly, the BHQ index showed a more or less successive increase over that time period. The fauna on two of the stations returned to Successional Stage (Fig. 2), but the two most severely hypoxiaaffected stations did not quite reach that stage during 
the two years of recovery. Thus, the benthic habitat quality also showed a rapid recovery. This was associated with a successively deeper penetration of the RPD indicative of increased bioturbation and irrigation processes. This demonstrates that the benthic faunal activity and their sedimentary habitat quality are closely linked.

In New Jersey, USA, hypoxia occurred for about 2 months in 1976. Following hypoxia, a few species returned to previous densities, but the recovery to the previous faunal structure was longer than 2 years (Boesch and Rosenberg, 1981). The authors pointed out that the resiliency of benthic communities to hypoxia is dependent on the constituent species, which have different life-cycles, reproduction periods and patterns of larval dispersion. In Kiel Bay in the southwest Baltic, the benthic communities were suggested to be pre-adapted to hypoxic conditions, especially in the inner part of the bay. These species had opportunistic features, they were fast growing and rapid colonisers, and they returned to pre-hypoxic conditions within about 1 year (Arntz, 1981). In a Swedish fjord, polluted by wastes from a sulphite pulp mill, the recovery to pre-disturbed conditions on 20 to $40 \mathrm{~m}$ deep bottoms took between 5 and 8 years. This comparatively slow recovery process was due to unfavourable sediment conditions with high organically enriched and reduced sediment with $\mathrm{H}_{2} \mathrm{~S}$ and fibres (Rosenberg, 1976). In shallow waters and defaunated sediments, the recovery process is generally much quicker and can be in the order of months (e.g. Santos and Simon, 1980).

\section{EUTROPHICATION AND HYPOXIA}

Eutrophication and hypoxia are spreading worldwide and have significant effects on benthic faunal succession. Eutrophication emerged as an increasing disturbance to coastal marine ecosystems in the 1980s (Rosenberg, 1985), but early warning signals were documented in the brackish Baltic Sea already in the 1960s (Fonselius, 1967). The increased input of nutrients and their effects on the ecosystem have been reported from Scandinavian waters (Ambio 1990, vol. 19). The secondary effects of eutrophication on benthic communities can be simplified as either an increase of food for the animals resulting in increased biomass (Josefson, 1990; Rosenberg et al., 1987), or lead to oxygen deficiency resulting in elimination of some species (Rosenberg et al., 1992) or communities with small individuals (Pearson et al., 1985; Josefson and Jensen, 1992). Gray (1992) presented a model of benthic faunal succession and effects on the animals in relation to different oxygen saturations in the near-bottom water (Fig. 7). The model has a similar layout as that in Figure 2, and Gray used information from (Baden et al., 1990). It is clear from Gray's model that increased oxygen saturations are correlated with a general increase in sediment RPD. Gray suggested that fish shows avoidance reactions in oxygen saturations between 25 and $40 \%$ and that behavioural responses to hypoxia in invertebrates occur at lower saturations.

In a review about the effects of hypoxia (generally defined as $\mathrm{O}_{2}$ concentrations $<2 \mathrm{ml} \mathrm{l}^{-1}$ ) on benthic macrofauna, Diaz and Rosenberg (1995) conclud-

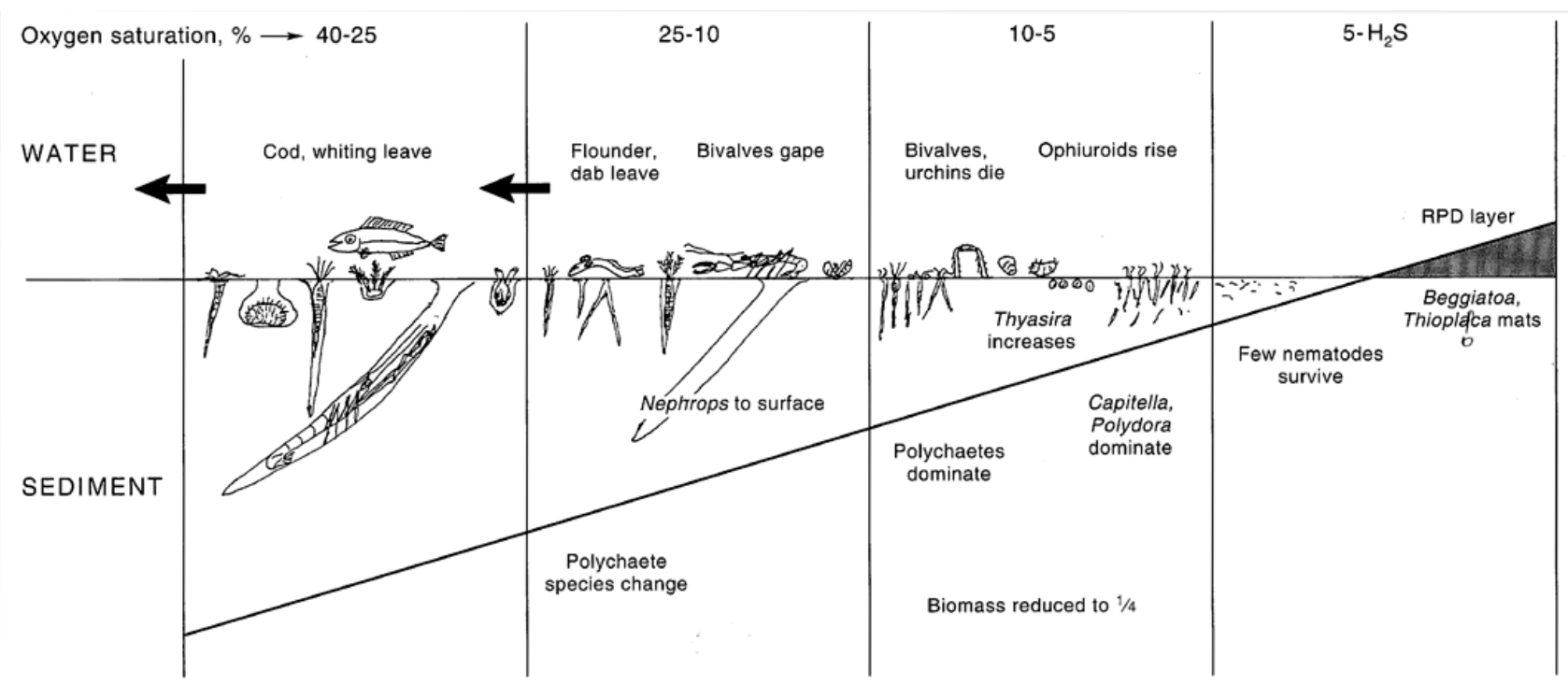

FIG. 7. - General model of benthic epifauna and infauna distribution and behavioural response to a gradient in oxygen saturation. The general change of redox potential discontinuity (RPD) along this gradient is also indicated (from Gray 1992). 
ed that the spread of hypoxia in coastal enclosed and stratified waters is a great threat to biodiversity. They stated that there is no other environmental variable of such ecological importance that has changed so drastically in such a short period as dissolved oxygen. The authors listed 44 marine systems around the world where hypoxia had caused negative effects on benthic communities. In a recent literature search, Diaz (pers. comm.) found 115 systems showing hypoxia-related effects on benthos. In the worst case of hypoxia, the benthic macrofauna is eliminated and then the 3-dimensional sedimentwater interface will be lost with consequences for biogeochemical processes. Jonsson et al. (1990) have shown the successive increase of laminated (non-bioturbated) bottoms from 1940 to 1990 , which recently covered about $70000 \mathrm{~km}^{2}$ or $1 / 3$ of the Baltic Sea bottoms. These bottom deserts are partly due to that the Baltic Sea is enclosed with irregular water renewal.

The only sensible way to stop the spread of eutrophication-induced hypoxia is to reduce the input of nutrients. In many areas nitrogen is the main limiting nutrient for primary production (Granéli et al., 1990). In some waters around Scandinavia, the target for nutrient reduction for restoring the ecosystem to its natural stage has been estimated at 50\% (Rosenberg et al., 1990). If measures are taken to reduce the eutrophication in such a way that nearbottom oxygen concentrations return to values before a disturbance was introduced, the recovery process for fauna and sedimentary habitats are likely to follow the successional models described above and may be a matter of a few years only.

\section{REFERENCES}

Aller, R.C. - 1988. Benthic fauna and biogeochemical processes in marine sediments: The role of burrow structures. In: T.H. Blackburn and J. Sorensen (eds.), Nitrogen Cycling in Coastal Marine Environments. pp. 301-338. Wiley.

Aller, R.C. and J.Y. Aller. - 1992. Meiofauna and solute transport in marine muds. Limnol. Oceanogr., 37: 1018-1033.

Aller, R.C. and J.Y. Aller. - 1998. The effect of biogenic irrigation intensity and solute exchange on diagenetic reaction rates in marine sediments. J. Mar. Res., 56: 905-936.

Arntz, W. - 1981. Zonation and dynamics of macrobenthos biomass in an area stressed by oxygen deficiency. In: G.W. Barrett and R. Rosenberg (eds.) Stress effects on natural ecosystems, pp. 215-225. John Wiley \& Sons, Chichester.

Arntz, W.E., J.M. Gili and K. Reise.- 1999. Unjustifiably ignored: Reflections on the role of benthos in marine ecosystems. In: J.S. Gray, W. Ambrose and A. Szaniawska (eds.), Biogeochemical Cycling and Sediment Ecology, pp. 105-124. J., Kluwer Academic Publishers, the Netherlands.

Astall, C.M., A.C. Taylor and R.J.A. Atkinson. - 1997. Behavioural and physiological implications of a burrow-dwelling lifecycle for two species od upogebiid mud-shrimp (Crustacea: Tha- lassinidea). Estuar. Coast. Shelf Sci., 44: 155-168.

Baden, S.P., L.O. Loo, L. Pihl and R. Rosenberg. - 1990. Effects of eutrophication on benthic communities including fish Swedish west coast. Ambio, 19: 113-122.

Boesch, D.F. and R. Rosenberg. - 1981. Response to stress in marine benthic communities. In: G.W. Barrett and R. Rosenberg (eds.), Stress effects on natural ecosystems, pp. 179-200. John Wiley \& Sons, Chichester.

Bonsdorff, E. and T.H. Pearson. - 1999. Variation in the sublittoral macrozoobenthos of the Baltic Sea along environmental gradients: A functional-group approach. Austr. J. Ecol., 24: 312-326.

Boudreau, B.P. - 1997a. A one-dimensional model for bed-boundary layer particle exchange. J. Mar. Syst., 11: 279-303.

Boudreau, B.P. - 1997b. Mean mixed depth of sediments: The wherefore and why. Limnol. Oceanogr., 43: 524-526.

Cloern, J.E. - 1982. Does benthos control phytoplankton biomass in south San Francisco Bay? Mar. Ecol. Prog. Ser., 9: 191-202.

Creutzberg, F., P. Wapenaar, G. Duineveld and N.L. Lopez. -1984. Distribution and density of the benthic fauna in the southern North Sea in relation to bottom characteristics and hydrographic conditions. Rapp. Proc.-Verb. Reun. Cons. Internat. L'explor. Mer. 183: 101-110.

Dauwe, B., P.M.J. Herman and C.H.R. Heip. - 1998. Community structure and bioturbation potential of macrofauna at four North Sea stations with contrasting food supply. Mar. Ecol. Prog. Ser., 173: 67-83.

Davey, J.T. - 1994. The architecture of burrow of Nereis diversicolor and its quantification in relation to sediment-water exchange. J. Exp. Mar. Biol. Ecol., 179: 115-129.

Davis, W.R. - 1993. The role of bioturbation in sediment resuspension and its interaction with physical shearing. J. Exp. Mar. Biol. Ecol., 171: 187-200.

Diaz, R.J. and R. Rosenberg. - 1995. Marine benthic hypoxia - review of its ecological effects and behavioural responses of marine macrofauna. Oceanogr. Mar. Biol. Ann. Rev., 33: 245-303.

Diaz, R.J. and L.C. Schaffner. - 1990. The functional role of estuarine benthos. In: M. Hairem and E.C. Krome (eds.), Perspectives on the Chesapeake Bay, 1990. Advances in estuarine sciences, pp. 25-56. Chesapeake Research Consortium, Golucester.

Duchêne, J.-C. and R. Rosenberg. - 2001. Marine benthic faunal activity on a sediment surface assessed by video numerical tracking. Mar. Ecol. Prog. Ser., (in press).

Eisma, D. and J. Kalf. - 1987. Distribution of organic content and particle size of suspended matter in the North Sea. Neth. J. Sea Res., 21: 265-286.

Fauchald, K. and P. Jumars. - 1979. The diet of worms; a study of polychaete feeding guilds. Oceanogr. Mar. Biol. Ann. Rev., 17: 193-284.

Fenchel, T. - 1996. Worm burrows and oxic microniches in marine sediments. 1. Spatial and temporal scales. Mar. Biol., 127: $289-295$.

Fonselius, S.H. - 1967. Hydrography of the Baltic deep basins II. Fishery Board of Sweden. Series Hydrography, Report no 20: $1-31$.

Forster, S. and G. Graf. - 1992. Continuously measured changes in redox potential influenced by oxygen penetrating from burrows of Callianassa subterranea. Hydrobiologia, 235/236: 527-532.

Gray, J.S. - 1992. Eutrophication in the sea. In: G. Colombo, I. Ferrari, V.U. Ceccherelli and R. Rossi (eds.), Marine Eutrophication and Population Dynamics, pp. 3-13. Olsen \& Olsen, Fredensborg, Denmark.

Gilbert, F., G. Stora and P. Bonin. - 1998. Influence of bioturbation on denitrification activity in Mediterranean coastal sediments: an in situ experimental approach. Mar. Ecol. Prog. Ser., 163: 99-107.

Graf, G. - 1992. Benthic-pelagic coupling: A benthic view. Oceanogr. Mar. Biol. Ann. Rev., 30: 149-190.

Graf, G., W. Bengtsson, U. Diesner, R. Schultz and H. Theede. 1982. Benthic response to sedimentation of a spring phytoplankton bloom: Progress and Budget. Mar. Biol., 67: 201-208.

Graf, G. and R. Rosenberg. - 1997. Bioresuspension and biodeposition: A review. J. Mar. Syst., 11: 269-278.

Granéli, E., K. Wallström, U. Larsson, W. Granéli and R. Elmgren. - 1990. Nutrient limitation of primary production in the Baltic Sea area. Ambio, 19: 142-151.

Heip, C. - 1995. Eutrophication and zoobenthos dynamics. Ophelia, 41: 113-136.

Hylleberg, J. and K. Henriksen. - 1980. The central role of biotur- 
bation in sediment mineralization and element re-cycling. Ophelia, Suppl. 1: 1-16.

Jenkins, M.C. and W.M. Kemp. - 1984. The coupling of nitrification and denitrification in two estuarine sediments. Limnol. Oceanogr., 29: 609-619.

Jonsson, P., R. Carman and F. Wulff. - 1990. Laminated sediments in the Baltic - a tool for evaluating nutrient mass balances. Ambio, 19: 152-158.

Josefson, A.B. - 1990. Increase of benthic biomass in the Skagerrak-Kattegat during the 1970s and 1980s - effects of organic enrichment? Mar. Ecol. Prog. Ser., 66: 117-130.

Josefson, A.B. and J.N. Jensen. - 1992. Effects of hypoxia on softsediment macrobenthos in southern Kattegat, Denmark. In: G. Colombo, I. Ferrari, V.U. Ceccherelli and R. Rossi (eds.) Marine eutrophication and population dynamics, pp. 21-28. Olsen \& Olsen, Fredensborg.

Jumars, P.A. and R.A. Wheatcroft. - 1989. Responses of benthos to changing food quality and quantity, with a focus on deposit feeding and bioturbation. In: W.H. Berger, V.S. Smetacek and G. Wefer (eds.), Productivity of the ocean: Present and past, pp. 235-253. J. Wiley \& Sons

Kristensen, E. and T.H. Blackburn. - 1987. The fate of organic carbon and nitrogen in experimental marine sediment systems: Influence of bioturbation and anoxia. J. mar. Res., 45: 231-257.

Lee, H.II and C. Swartz. - 1980. Biological processes affecting the distribution of pollutants and marine sediments. Part II. Biodepostion and bioturbation. In: R.A. Baker (ed.), Contaminents and sediments, pp. 555-606. AnnArbor Science Publ., AnnArbor, MI.

Levin, L., N. Blair, D. De Master, G. Plaia, W. Fornes, C. Martin and C. Thomas. -1997 . Rapid subduction of organic matter by maldanid polychaetes on the North Carolina slope. J. Mar. Res., 55: 595-611.

Loo, L.O. and R. Rosenberg. - 1989. Bivalve suspension-feeding dynamics and benthic-pelagic coupling in an eutrophicated marine bay. J. Exp. Mar. Biol. Ecol., 130: 253-276.

Lopez, G.R. and J.S. Levington. - 1987. Ecology of deposit-feeding animals in marine sediment. Ouarte. rev. Biol., 62: 235-235.

Margalef, R.. - 1968. Perspectives in Ecological Theory. Univ. Chicago Press, Chicago, 111 pp.

Mayer, M.S., L. Schaffner and W.M. Kemp. - 1995. Nitrification potentials of benthic macrofaunal tubes and burrow walls: effects of sediment $\mathrm{NH}_{4}+$ and animal irrigation behavior. Mar. Ecol. Prog. Ser., 121: 157-169.

Molander, A. - 1928. Animal communities on soft bottom areas in the Gullmar Fjord. Kristinebergs Zool. Stat., 2: 1-90.

Möller, P. and R. Rosenberg. - 1983. Recruiment, abundance and production of Mya arenaria and Cardium edule in marine shallow waters, western Sweden. Ophelia, 22: 33-55.

Nilsson, H.C. and R. Rosenberg. - 1997. Benthic habitat quality assessment of an oxygen stressed fjord by surface and sediment profile images. J. Mar. Syst., 11: 249-264.

Nilsson, H.C. and R. Rosenberg. - 2000. Succession in marine benthic habitats and fauna in response to oxygen deficiency: analysed by sediment profile imaging and by grab samples. Mar. Ecol. Prog. Ser., 197: 139-149.

Ockelmann, K.W. and K. Muus. - 1978. The biology, ecology and behaviour of the bivalve, Mysella bidentata. Ophelia, 17: 1-93.

Ott, J.A. - 1992. The Adriatic benthos: problems and perspectives. In: G. Colombo, I. Ferrari, V.U. Ceccherelli and R. Rossi (eds.), Marine Eutrophication and Population Dynamics, pp. 367-378 Olsen \& Olsen, Fredensborg, Denmark.

Pearson, T.H., A.B. Josefson and R. Rosenberg. - 1985. Petersen's benthic stations revisited. I. Is the Kattegatt becoming eutrophic? J. Exp. Mar. Biol. Ecol., 92: 157-206.

Pearson, T.H. and R. Rosenberg. - 1978. Macrobenthic succession in relation to organic enrichment and pollution of the marine environment. Oceanogr. Mar. Biol. Ann. Rev., 16: 229-311.

Pearson, T.H. and R. Rosenberg. - 1987. Feast and famine: Structuring factors in marine benthic communities. In: J.H.R. Gee and P.S. Giller (eds.), The 27th Symposium of The British Ecological Society, Aberystwyth 1986, pp. 373-395. Blackwell Scientific Publications, Oxford.

Petersen, C.G.J. - 1913. Valuation of the sea. 2. The animal communities of the sea bottom and their importance for marine zoogeography. Rep. Dan. Biol. Ann. Rev., 16: 229-311.
Petersen, J.K. and H.U. Riisgård. - 1992. Filtration capacity of the ascidian Ciona intestinalis and its grazing impact in a shallow fjord. Mar. Ecol. Prog. Ser., 88: 9-17.

Revsbech, N.P., J. Sørensen and T.H. Blackburn. - 1980. Distribution of oxygen in marine sediments measured with microelectrodes. Limnol. Oceanogr., 25: 403411.

Rhoads, D.C., 1974. - Organism sediment relations on the muddy sea floor. Oceanogr. Mar. Biol. Ann. Rev., 12: 263-300.

Rhoads, D.C. and S. Cande. - 1971. Sediment profile camera for in situ study of organism-sediment relations. Limnol. Oceanogr., 16: $110-114$

Rhoads, D.C. and J.D. Germano. - 1982. Characterization of organism-sediment relations using sediment profile imaging: An efficient method of remote ecological monitoring of the seafloor. Mar. Ecol. Prog. Ser., 8: 115-128.

Rhoads, D.C. and J.D. Germano. - 1986. Interpreting long-term changes in benthic community structure: a new protocol. Hydrobiologia, 142: 291-308.

Rosenberg, R. - 1976. Benthic faunal dynamics during succession following pollution abatement in a Swedish estuary. Oikos, 27: 414-427.

Rosenberg, R. - 1985. Eutrophication-the future marine coastal nuisance? Mar. Pollut. Bull., 16: 227-231.

Rosenberg, R. - 1995. Benthic marine fauna structured by hydrodynamic processes and food availability. Neth. J. Sea Res., 34: 303-317.

Rosenberg, R., R. Elmgren, S. Fleischer, P. Jonsson, G. Persson and H. Dahlin. - 1990. Marine eutrophication case studies in Sweden. Ambio, 19: 102-108.

Rosenberg, R., J.S. Gray, A.B. Josefson and T.H. Pearson. - 1987. Petersen's benthic stations revisited. II. Is the Oslofjord and eastern Skagerrak enriched? J. Exp. Mar. Biol. Ecol., 105: 219-251.

Rosenberg, R., L.-O. Loo and P. Möller. - 1992. Hypoxia, salinity and temperature as structuring factors for marine benthic communities in an eutrophic area. Neth. J. Sea Res., 30: 121-129.

Rosenberg, R., H.C. Nilsson, K. Hollertz and B. Hellman. - 1997. Density-dependent migration in an Amphiura filiformis (Amphiuridae, Echinodermata) infaunal population. Mar. Ecol. Prog. Ser., 159: 121-131.

Rosenberg, R., H.C. Nilsson and R.J. Diaz. - 2001. Response of benthic fauna and changing sediment redox profiles over a hypoxic gradient. Estuar. Coast. Shelf Sci., (in press).

Sandnes, J., T. Forbes, R. Hansen, B. Sandnes and B. Rygg. - 2000. Bioturbation and irrigation in natural sediments described by animal community patterns. Mar. Ecol. Prog. Ser., 197: 169-179.

Santos, S.L. and J.L. Simon. - 1980. Marine soft-bottom community establishment following annual defaunation: Larval or adult recruitment? Mar. Ecol. Prog. Ser., 2: 235-241.

Schaffner, L. - 1990. Small-scale organism distributions och patterna of species diversity:evidence for positive interactions in an estuarine benthic community. Mar. Ecol. Prog. Ser., 61: 107-117.

Smetacek, V. - 1984. The supply of food to the benthos. In: M.J. Fasham (ed.), Flows of energy and materials in marine ecosystems: theory and practices. pp. 517-547, Plenum Press, N.Y.

Taghon, G.L. and R.R. Greene. - 1992. Utilization of deposited and suspended particulate matter by benthic "interface" feeders. Limnol. Oceanogr., 37: 1370-1391.

Thomsen, L., G. Graf, K.v. Juterzenka and U. Witte. - 1995. An in situ experiment to investigate the depletion of seston above an interface feeder field on the continental slope of the western Barents Sea. Mar. Ecol. Prog. Ser., 123: 295-300.

Thorson, G. - 1957. Bottom communities (sublittoral or shallow shelf). Geol. Soc. Am. Memoir 67, 1: 461-534.

Wassmann, P. - 1990. Calculating the load of organic carbon to the aphotic zone in eutrophicated coastal waters. Mar. Pollut. Bull., 21: 183-187.

Widdicombe, S. and M.C. Austen. - 1998. Experimental evidence for the role of Brissopsis lyrifera (Forbes, 1841) as a critical species in the maintenance of benthic diversity and the modification of sediment chemistry. J. Exp. Mar. Biol. Ecol., 228: 241-255.

Zajac, R.N. and R.B. Whitlatch. - 1982. Responses of estuarine infauna to disturbance. I. Spatial and temporal variation of initial recolonization. Mar. Ecol. Prog. Ser., 10: 1-14. 